\title{
PENGARUH PEMBERIAN EKSTRAK DAUN KEPEL (Stelechocarpus burahol) TERHADAP KADAR KOLESTEROL DARAH DAN TELUR PUYUH (Coturnix-coturnix japonica)
}

\section{The Effect Of Giving Kepel Leaf Extract (Stelechocarpus burahol) On Blood And Egg Quail (Coturnix-coturnix japonica) Cholesterol Level}

\author{
Ismara Ayunda Ramadhina ${ }^{1}$, Lovita Adriani ${ }^{2}$, Endang Sujana ${ }^{2}$ \\ ${ }^{1}$ Mahasiswa Program Sarjana Ilmu Peternakan, \\ Fakultas Peternakan Universitas Padjadjaran \\ ${ }^{2}$ Fakultas Peternakan Universitas Padjadjaran \\ Kampus Jatinangor, Jalan Raya Bandung-Sumedang KM. 21 \\ Sumedang 45363, Jawa Barat
}

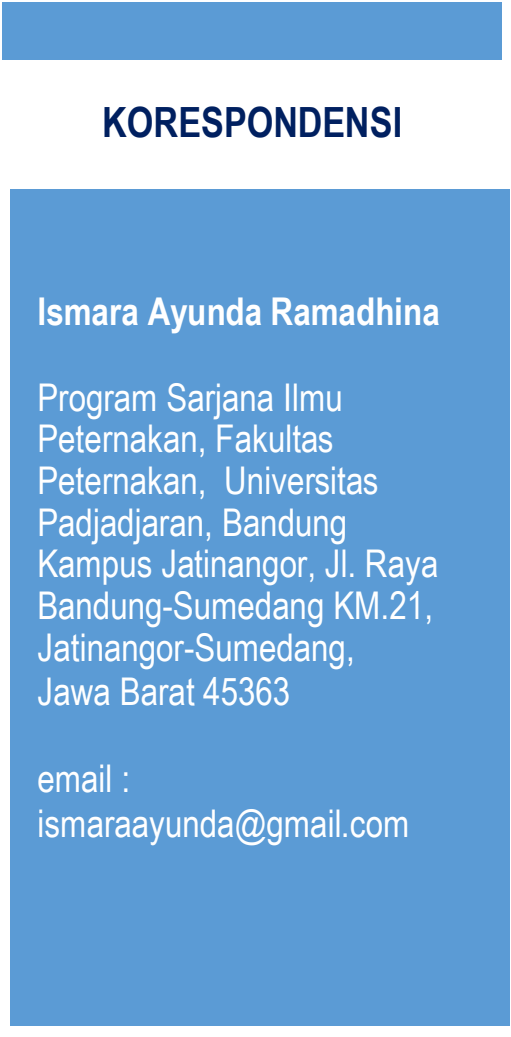

\begin{abstract}
ABSTRAK
Penelitian dengan judul "Pengaruh Pemberian Ekstrak Daun Kepel (Stelechocarpus burahol) Terhadap Kadar Kolesterol Darah Dan Telur Puyuh (Coturnix-coturnix japonica)" telah dilaksanakan pada bulan Juni-September 2019 di Pusat Pembibitan Puyuh Fakultas Peternakan Universitas Padjadjaran, dan Laboratorium Fisiologi dan Biokimia, Fakultas Peternakan, Universitas Padjadjaran. Penelitian ini bertujuan untuk mengetahui kadar kolesterol darah dan telur (yolk) puyuh yang diberi perlakuan ekstrak daun kepel (Stelechocarpus burahol). Penelitian ini menggunakan metode eksperimental dengan Rancangan Acak Lengkap (RAL). Terdapat 20 unit perlakuan yang terdiri atas 5 perlakuan dan 4 ulangan, dengan dosis perlakuan ekstrak daun kepel yaitu : $\mathrm{P}_{0}=0 \mathrm{mg} / \mathrm{kgBB}, \mathrm{P}_{1}=200 \mathrm{mg} / \mathrm{kgBB}, \mathrm{P}_{2}=$ $300 \mathrm{mg} / \mathrm{kgBB}, \mathrm{P}_{3}=400 \mathrm{mg} / \mathrm{kgBB}$, dan $\mathrm{P}_{4}=500 \mathrm{mg} / \mathrm{kgBB}$. Puyuh yang digunakan dalam penelitian ini sebanyak 80 ekor. Hasil penelitian menunjukkan kadar koelsterol darah pada setiap perlakuan tidak berbeda nyata $(\mathrm{P}>0,05)$, tetapi berbeda nyata $(\mathrm{P}<0,05)$ terhadap kadar kolesterol telur. Kesimpulan yang dapat diambil ialah pemberian ekstrak
\end{abstract} daun kepel ( $S$. burahol) belum mampu menurunkan kadar kolesterol darah, namun pada dosis $200 \mathrm{mg} / \mathrm{kgBB}$ dapat menurunkan kadar kolesterol telur.

Kata Kunci: kepel, kolesterol, puyuh 


\section{ABSTRACT}

The research entitled "The Effect Of Giving Kepel Leaf Extract (Stelechocarpus burahol) On Blood And Egg Quail (Coturnix-coturnix japonica) Cholesterol Level" was conducted in Quail Breeding Center, and Physiology and Biochemistry Laboratory, Animal Husbandry Faculty, Padjadjaran University from June until September 2019. The research uses an experimental method with a Completely Randomized Design (CDR). There are 20 units consisting of 5 treatments and 4 replications, with the treatment dose of Kepel leaf extract such as : $P_{0}=0$ $\mathrm{mg} / \mathrm{kgBW}, \quad P_{1}=200 \mathrm{mg} / \mathrm{kgBW}, P_{2}=300 \mathrm{mg} / \mathrm{kgBW}, P_{3}=400 \mathrm{mg} / \mathrm{kgBW}$, and $P_{4}=500$ $m g / k g B W$. This research uses 80 quails. The results of this research showed that effect of giving kepel extract leaf was non significant difference $(P>0,05)$ decrease on blood cholesterol but significant $(P<0,05)$ on egg cholesterol. The conclusion is giving kepel leaf extract doesn't capable to decrease blood cholesterol but dose $200 \mathrm{mg} / \mathrm{kgBW}$ can decrease egg cholesterol.

Keywords: $\quad$ Kepel extract, cholesterol, quail

\section{PENDAHULUAN}

Pertumbuhan penduduk Indonesia semakin hari semakin meningkat. Kesadaran akan kesehatan masyarakat semakin memperhitungkan tentang pentingnya gizi bagi kehidupan salah satunya adalah asupan dari protein hewani, maka permintaan protein hewani salah satunya berasal dari telur pun meningkat. Salah satu sumber protein hewani potensial di Indonesia yaitu puyuh. Namun dilihat dari salah satu nutrientnya, yaitu kolesterol terdapat kendala yaitu kandungan kolesterol darah yang diduga akan berkorelasi dengan kolesterol telur puyuh ini cukup tinggi, hal ini yang menjadi masyarakat Indonesia terutama pada usia lanjut kurang berminat untuk mengkonsumsi telur puyuh.

Telur berkontribusi dalam pemenuhan konsumsi sumber protein hewani asal ternak bagi masyarakat. Telur merupakan sumber gizi lengkap yang harganya relatif murah, mudah didapatkan, dan diolah sehingga dijangkau masyarakat yang perekonomiannya menengah kebawah.

Puyuh adalah salah satu komoditi peternakan yang efisien dalam menyediakan protein, baik berasal dari telur dan daging karena merupakan bahan makanan dengan sumber pangan hewan yang cukup tinggi (Handarini dkk, 2008). Keuntungan dalam beternak puyuh, yaitu umur enam minggu puyuh sudah berproduksi, tidak membutuhkan permodalan yang besar, mudah pemeliharaannya serta dapat diusahakan pada lahan yang terbatas (Nixon, 2008).

Kandungan gizi yang ada dalam telur salah satunya yaitu kolesterol, kadar kolesterol yang tinggi tentunya dipengaruhi dari komposisi ransum yang diberikan kepada ternak. Meningkatnya kandungan kolesterol dalam telur puyuh diduga dipengaruhi dari tingginya kolesterol dalam darah. Pemberian feed additive yang mengandung antioksidan, diperlukan untuk mengontrol kondisi fisiologi kolesterol darah dan kolesterol telur.

Stelechocarpus burahol atau dikenal dengan nama kepel secara tradisional digunakan sebagai obat untuk menurunkan kolesterol dan kadar asam urat (Hidayat, 2015). Tanaman kepel memiliki kandungan kimia polifenol terutama terdapat pada daunnya (Tersono, 2008). Daun kepel mengandung senyawa saponin, flavonoid, polifenol, dan isoflavon (BPOM RI, 2011).

Pemberian ekstrak daun kepel (Stelechocarpus burahol) dengan dosis 50 $\mathrm{mg} / \mathrm{kgBB}, 100 \mathrm{mg}$ per $\mathrm{kgBB}$, dan $200 \mathrm{mg}$ per $\mathrm{kgBB}$ dengan bobot badan mencit 20-30 gram ekor menunjukkan efek positif pada mencit jantan galur BALB/C dapat menurunkan kadar kolesterol total darah mencit yang diinduksi ekstrak daun kepel 
dengan hasil berturut-turut adalah 18,66 \pm $11,20 \% ; 21,35 \pm 2,94 \%$; dan 12,82 $\pm 2,29 \%$. Kadar trigliserida darah mencit yang diberi ekstrak daun kepel (Stelechocarpus burahol) dosis $50 \mathrm{mg} / \mathrm{kgBB}, 100 \mathrm{mg} / \mathrm{kgBB}$, dan 200 $\mathrm{mg} / \mathrm{kgBB}$ berturut-turut adalah 21,68 \pm $14,86 \% ; 21,12 \pm 4,95 \%$; dan 39,71 $\pm 13,56 \%$. Berdasarkan hasil tersebut dapat diketahui bahwa penurunan kadar kolesterol total darah mencit tertinggi ditunjukkan oleh pemberian ekstrak daun kepel (Stelechocarpus burahol) dengan dosis $100 \mathrm{mg}$ per $\mathrm{kgBB}$, sedangkan dalam menurunkan kadar trigliserida darah mencit yang diinduksi aloksan dosis paling efektif dimiliki oleh kelompok ekstrak daun kepel (Stelechocarpus burahol) dosis $200 \mathrm{mg}$ per kgBB secara oral (Rosi, 2018).

Tanaman ini belum banyak dilakukan penelitian terhadap kadar kolesterol darah dan telur pada ternak, hal ini yang membuat penulis melakukan penelitian ini yang diujikan pada puyuh petelur, karena masih belum banyak yang meneliti tentang manfaat daun kepel terhadap ternak.

\section{METODE PENELITIAN}

Bahan utama yang digunakan dalam penelitian ini adalah plasma darah puyuh, kuning telur puyuh, dan ekstrak daun kepel. Alat yang digunakan yaitu : Gunting, karung, timbangan digital, label, alat tulis, labu erlenmayer, labu ukur, timbangana analitik, cawan petri, rotary evaporator, corong buchner, pompa vakum, kandang puyuh individu, lampu, selongsong kayu, tempat minum, egg tray, spluit dan siring ukuran 1 $\mathrm{ml} \& 3 \mathrm{ml}$, tabung EDTA, cool box, spektrofotemer, kuvet, spatula, nampan, alumunium foil, pipet piston, pipet tip $10 \mu 1$ dan $1000 \mu$ l. Cara kerja dalam penelitian ini meliputi persiapan kandang individu, pembuatan ekstrak daun kepel, pembuatan ransum basal, dan uji analasis sampel darah $\&$ telur puyuh.

Prosedur pembuatan ekstrak daun kepel (S. burahol) yaitu :

Sampel $4.000 \mathrm{~g}$ daun kepel segar, dikeringkan dan dipotong kecil-kecil. Sampel daun kepel kering ditimbang sebanyak 2000 g. Kemudian dimaserasi dengan etanol selama 2 hari. Ekstrak etanol $70 \%$ hasil maserasi disaring dengan corong saring dan ditampung filtratnya. Filtrat tersebut selanjutnya dievaporasi menggunakan alat rotary evaporator pada suhu $\pm 40^{\circ} \mathrm{C}$ sehingga diperoleh ekstrak pekat etanol 1,937 g.

Bahan pakan penyusun ransum basal terdiri atas : jagung, dedak halus, bungkil kedelai, tepung ikan, mineral, grit, premix, lisin dan metionin. Kandungan nutrien dan energi metabolis ransum basal seperti disajikan pada Tabel 1.

Penelitian ini menggunakan metode eksperimental dengan Rancangan Acak Lengkap (RAL). Terdapat 20 unit perlakuan yang terdiri atas 5 perlakuan dan 4 ulangan, dengan dosis perlakuan ekstrak daun kepel yaitu : $\mathrm{P}_{0}=0 \mathrm{mg} / \mathrm{kgBB}, \mathrm{P}_{1}=200 \mathrm{mg} / \mathrm{kgBB}$, $\mathrm{P}_{2}=300 \mathrm{mg} / \mathrm{kgBB}, \mathrm{P}_{3}=400 \mathrm{mg} / \mathrm{kgBB}$, dan $\mathrm{P}_{4}=500 \mathrm{mg} / \mathrm{kgBB}$. Puyuh yang digunakan dalam penelitian ini sebanyak 80 ekor. Data yang diperoleh dianalisis dnegan uji sidik ragam ANOVA dan pengaruh perlakuan menggunakan uji lanjut Duncan.

Tabel 1. Kandungan Nutrient dan Energi Metabolis Ransum Basal

\begin{tabular}{lcc}
\hline Kandungan Nutrient & Kandungan & $\begin{array}{c}\text { *Kebutuhan } \\
\text { (NRC 1994) }\end{array}$ \\
\hline Energi metabolis (Kkal/kg) & 2901,08 & 2900,00 \\
Protein kasar (\%) & 20,91 & 20,00 \\
Calsium (\%) & 2,58 & 2,50 \\
Phospor (\%) & 0,75 & 0,35 \\
Lisin (\%) & 1,50 & 1,00 \\
Metionin (\%) & 0,53 & 0,45 \\
\hline
\end{tabular}




\section{HASIL DAN PEMBAHASAN}

Kandungan kolesterol darah puyuh yang sudah diberi perlakuan ekstrak daun kepel maka didapatkan hasil analisis laboratorium, disajikan dalam Tabel 2. Tabel 2 di atas menunjukkan kadar kolesterol darah puyuh perlakuan berada pada kisaran 157,206-267,517 $\mathrm{mg} / \mathrm{dl}$, dengan rataan terendah sampai yang tertinggi secara berurutan yaitu 157, $206 \mathrm{mg} / \mathrm{dl}\left(\mathrm{P}_{4}\right), 174,279$ $\mathrm{mg} / \mathrm{dl}\left(\mathrm{P}_{0}\right), 212,972 \mathrm{mg} / \mathrm{dl}\left(\mathrm{P}_{1}\right), 229,933$ $\mathrm{mg} / \mathrm{dl} \quad\left(\mathrm{P}_{2}\right)$ dan 267,517 mg/dl $\left(\mathrm{P}_{3}\right)$. Uji statistik dilakukan untuk mengetahui pengaruh perlakuan terhadap kadar kolesterol darah. Hasil analisis statistik menunjukkan bahwa semua perlakuan menggunakan ekstrak daun kepel memberikan pengaruh berbeda tidak nyata $(\mathrm{P}>0,05)$ terhadap kadar kolesterol darah puyuh. Hasil menunjukkan bahwa semua perlakuan ekstrak daun kepel secara statistika tidak memberikan pengaruh menurunkan kolesterol darah puyuh, namun hasil tersebut menunjukkan rata-rata kolesterol darah puyuh masih dalam batas normal. Hal ini sesuai dengan hasil penelitian Blaszczyk, et al (2006) bahwa kandungan kolesterol darah puyuh betina periode produksi berkisar antara $180-220 \mathrm{mg} / \mathrm{dl}$.

Kadar kolesterol darah puyuh yang diberi perlakuan ekstrak daun kepel
(S.burahol) hasilnya tidak berpengaruh nyata, diduga karena kolesterol darah banyak bersumber dari proses endogen sebanyak $75 \%$, sedangkan $25 \%$ bersumber dari proses eksogen yang berasal dari pakan, yang dimana di proses metabolisme itu terdapat Acetyl Co-A sampai menjadi mevalonat yang dimediasi oleh HMG Co-A ke sel yang belum bisa dihambat oleh zat aktif ekstrak daun kepel, sehingga perlakuan $\mathrm{P}_{1}, \mathrm{P}_{2}$, dan $\mathrm{P}_{3}$ ekstrak daun kepel masih belum bisa memberikan pengaruh terhadap kolesterol darah. Namun pada perlakuan $\mathrm{P}_{4}$ zat aktif senyawa flavonoid, saponin dan polifenol pada ekstrak daun kepel memberikan pengaruh dengan menurunnya kadar kolesterol darah puyuh sebanyak 9,79\%. Flavonoid dapat menghambat sintesis kolesterol endogen dengan menghambat enzim HMG CoA reduktase yang bertindak sebagai perantara sintesis mevalonat yang akhirnya menjadi kolesterol (Adriani dkk, 2014). Fungsi HMG CoA reduktase adalah enzim untuk merubah HMG CoA menjadi mevalonat, sehingga apabila HMG CoA reduktase dihambat, maka mevalonat terhambat atau tidak dapat terbentuk (Casachi dan Ogawa cit Rianti, 2013; Mushawwir dan Latipudin, 2013; Mushawwir, 2015; ).

Tabel 2. Kadar Kolesterol Plasma Darah dan Telur Puyuh

\begin{tabular}{ccc}
\hline Perlakuan & Plasma Darah $(\mathbf{m g} / \mathbf{d L})$ & Telur $(\mathbf{m g} / \mathbf{d L})$ \\
\hline $\mathrm{P}_{1}$ & $112,860^{\mathrm{a}}$ & $212,972^{\mathrm{a}}$ \\
$\mathrm{P}_{2}$ & $213,008^{\mathrm{ab}}$ & $229,933^{\mathrm{a}}$ \\
$\mathrm{P}_{0}$ & $240,798^{\mathrm{b}}$ & $171,279^{\mathrm{a}}$ \\
$\mathrm{P}_{3}$ & $241,906^{\mathrm{b}}$ & $267,517^{\mathrm{a}}$ \\
$\mathrm{P}_{4}$ & $336,696^{\mathrm{b}}$ & $157,206^{\mathrm{a}}$ \\
\hline $\begin{array}{l}\text { Keterangan } \\
\text { : Rata-rata yang diikuti notasi yang berbeda pada kolom sama menunjukkan } \\
\text { berbeda nyata }(\mathrm{P}<0,05) .\end{array}$
\end{tabular}


Saponin adalah jenis glikosida yang banyak ditemukan dalam tumbuhan, memiliki karakteristik berupa buih, bersifat emulsi dapat digunakan untuk menurunkan kolesterol serum (Robinson 1995; Harborne 1987). Saponin dapat menurunkan kolesterol plasma darah dengan cara saponin akan berikatan dengan asam empedu dan meningkatkan ekskresi asam empedu di dalam feses dan sterol netral (seperti koprostanol dan kolestanol) (Messina, 1999; Lee, 2005). Hal ini menyebabkan konversi kolesterol menjadi asam empedu sangat meningkat untuk upaya mempertahankan depot asam empedu. Konsekuensinya reseptor LDL dari hati akan dinaikkan sehingga terjadi peningkatan pengambilan LDL yang akan disertai dengan penurunan kadar kolesterol plasma darah.

Senyawa polifenol dapat menurunkan kadar kolesterol plasma darah dengan cara polifenol berikatan dengan kolesterol sehingga kolesterol yang diserap sedikit, sedangkan sisa dari kolesterol yang tidak diserap dieksresikan melalui feses (Yokozawa et al, 2002).

Berdasarkan Tabel 2, menunjukkan rataan kadar kolesterol telur puyuh pada perlakuan yaitu berkisar antara 112,860$336,696 \mathrm{mg} / \mathrm{dl}$, dengan rataan terendah sampai tertinggi secara berurutan yaitu 112, $860 \mathrm{mg} / \mathrm{dl}\left(\mathrm{P}_{1}\right), 213,008 \mathrm{mg} / \mathrm{dl}\left(\mathrm{P}_{2}\right), 240,798$ $\mathrm{mg} / \mathrm{dl}\left(\mathrm{P}_{0}\right), 241,906\left(\mathrm{P}_{3}\right)$, dan 336, $696\left(\mathrm{P}_{4}\right)$.

Hasil analisis ragam menunjukkan bahwa pemberian ekstrak daun kepel (Stelechocarpus burahol) memberikan pengaruh nyata $(\mathrm{P}<0,05)$ terhadap kadar kolesterol telur puyuh. Guna untuk mengetahui pengaruh perlakuan terhadap kadar kolesterol telur puyuh dilakukan uji jarak berganda Duncan yang hasilnya ditampilkan pada Tabel 2.

Tabel 2 menunjukkan bahwa perlakuan $\mathrm{P}_{1}$ (200 mg per $\mathrm{kgBB}$ ) tidak berbeda nyata $(\mathrm{P}>0,05)$ dengan $\mathrm{P}_{2}$ (300 mg per $\left.\mathrm{kgBB}\right)$, namun berbeda nyata $(\mathrm{P}<0,05)$ dengan perlakuan $\mathrm{P}_{0}(0 \mathrm{mg}$ per $\mathrm{kgBB}), \mathrm{P}_{3}(400 \mathrm{mg}$ per $\mathrm{kgBB}$ ) dan $\mathrm{P}_{4}\left(500 \mathrm{mg}\right.$ per $\mathrm{kgBB}$ ), lalu $\mathrm{P}_{2}$ (300 mg per $\mathrm{kgBB}$ ) tidak berbeda nyata
( $\mathrm{P}>0,05)$ dengan $\mathrm{P}_{0}(0 \mathrm{mg}$ per $\mathrm{kgBB}), \mathrm{P}_{3}(400$ $\mathrm{mg}$ per $\mathrm{kgBB}$ ), dan $\mathrm{P}_{4}(500 \mathrm{mg}$ per $\mathrm{kgBB}$ ). Perbedaan ini disebabkan oleh adanya aktivitas senyawa aktif dalm ekstrak daun kepel terhadap kadar kolesterol telur puyuh.

Rataan kadar kolesterol telur puyuh yang terendah yang diberi perlakuan $\mathrm{P}_{1}$ (200 $\mathrm{mg}$ per $\mathrm{kgBB}$ ) dengan hasil rataan kadar kolesterol telur 112, $860 \mathrm{mg} / \mathrm{dl}$, dengan persentase penurunan kolesterol telur sebesar 53, 130\% . Hasil kolesterol telur di penelitian ini lebih rendah dibandingkan dengan penelitian Nuraini (2012) yang dimana kolesterol telur tersebut sebesar 264,75 $\mathrm{mg} / \mathrm{dl}$. Kolesterol telur puyuh dapat turun, hal ini dikarenakan senyawa aktif yang terdapat pada daun kepel (S. burahol) yaitu flavonoid berupa isoflavon yang efektif menghambat sintesis kolesterol pada telur.

Dosis $200 \mathrm{mg}$ per kgBB ekstrak daun kepel lebih efektif menurunkan kadar kolesterol telur dibandingkan dengan dosis lainnya $300 \quad \mathrm{mg} / \mathrm{kgBB}-500 \quad \mathrm{mg} / \mathrm{kgBB}$ dikarenakan pada proses distrubusi kolesterol terhadap telur sudah digunakan untuk beberapa kepentingan, yaitu proses sintesis vitelogenin dan pembelahan proteolitik dari vitelogenin menjadi subunit lipoprotein kuning telur. Kemudian senyawa flavonoid hanya dapat diserap saluran pencernaan maksimal tidak lebih dari $1 \mu \mathrm{mol} / \mathrm{L}$ (Halliwel, 2005).

Hasil penelitian ini sesuai dengan BPOM RI (2011) pada daun kepel (S.burahol) terbukti mengandung senyawa saponin, flavonoid, polifenol, dan isoflavon. Sunarni (2007) menyatakan daun kepel ( $S$. burahol) dimanfaatkan secara empiris untuk mengatasi asam urat, dan menurunkan kadar kolesterol. Pada penelitian lain flavonoid dalam jeruk telah terbukti menurunkan tekanan darah tinggi dan kolesterol pada hewan percobaan, dan memiliki sifat antiimflamasi (Adriani dkk, 2014).

Hasil penelitian ini sesuai dengan penelitian Elkin (2006) menyatakan bahwa flavonoid berupa isoflavon bertindak sebagai phytoestrogen yang memicu biosintesis vitellogenin di hati. Vitellogenin kemudian 
masuk ke dalam aliran darah menuju ovarium sebagai salah satu prekursor dari kuning telur (yolk). Senyawa phytoestrogen akan menstimulasi pembentukan folikel di dalam ovarium sehingga jumlah folikel yang berkembang akan meningkat, menyebabkan lemak dan kolesterol yang membentuk kuning telur akan di distribusikan ke perkembangan folikel yang lebih banyak, sehingga kadar lemak dan kolesterol dalam telur akan mengalami penurunan (Elkin 2006; Saraswati 2013)

Pada pemberian dosis $300 \mathrm{mg}$ per $\mathrm{kgBB}-500 \mathrm{~kg}$ per $\mathrm{kgBB}$ tersebut, kolesterol telur puyuh meningkat, diduga karena kandungan senyawa flavonoid pada dosis tersebut terlalu berlebihan sehingga menyebabkan hepatoxic, sesuai dengan penelitian Halliwel (2005) bahwa, bertambahnya dosis tidak akan meningkatkan efek namun akan memberikan dampak yang akan tidak diinginkan. Hal ini sesuai dengan hasil penelitian Wang (2011) dimana dosis rendah memberikan efek protektif namun dosis tinggi memberikan efek hapatoxic.

\section{KESIMPULAN}

1) Pemberian ekstrak daun kepel tidak berpengaruh menurunkan kolesterol darah, namun berpengaruh menurunkan kolesterol telur puyuh.

2) Pemberian ekstrak daun kepel berpengaruh menurunan kadar kolesterol telur puyuh sebanyak 53,130\%, dengan perlakuan $\mathrm{P}_{1}(200 \mathrm{mg}$ per $\mathrm{kgBB}$ )

\section{DAFTAR PUSTAKA}

Abun, H., Wicaksono. A dan Wiradimadja. R. 2015. Pengaruh Penggunaan Limbah Udang Produk Fermentasi dalam Ransum terhadap Konversi Protein Ransum dan Daging pada Ayam Lokal. Unpad Press. Bandung.

Adriani. L, E. Hernawan, U. Hidayat. 2014. Decreasing Cholesterol and Triglyceride level On Blood By Adding Orange (Citrus sinensis) Waste On Padjadjaran I Sheep. Scientific Papers.
Series. D. Animal Science. Vol. LVII, 2014.

Adriani. L., M. Elfa and D. Latipudin. 2014. Effects of Sweet Orange (Citrus sinensis) Waste Meal in Ration on Blood Glucose, Cholesterol Level in Meat Quails. Journal Of Animal Science. Selskostopanska Akademiya Rusia. Vol. LI Sofia : 1-2/2014.

Blaszczyk, B., T. U, Zofia., Darius, G. Tomasz, S., Danuta, S. Krystyna, R., dan Joanna, J. 2006. Changes in the Blood Plasma Testosterone and Cholesterol Concentrations During Sexual Maturation of Pharaoh Quails. Animal Science Papers and Reports. 24:259-266.

BPOM RI. 2011. Acuan Sediaan Herbal. Volume 6 Edisi I. BPOM. Jakarta.

Casachi dkk. 2004 dan Ogawa dkk. 2005. Dalam Ranti G.C., Fatmawati, Wehantouw F. 2013. Uji Efektivitas Ekstrak Flavonoid dan Steroid dari Gedi (Abelmoschus manihot) sebagai Anti Obestian dan Hipolipidemik pada Tikus Putih Jantan Galur Wistar. Jurnal Ilmiah Farmasi. UNSTRAT. 2:12-17.

Elkin, R. G. 2006. Reducing Shell Egg Cholesterol. Overview Genetics Approaches and Nutritional Strategies. World Poultry Science. 62:665-687.

Halliwel B, J. Rafter, and A. Jenner. 2005. Health Promotion By Flavanoids, Tocopherols, Tocotrienols, and Other Phenlos : Direct or Indirect, Antioxidant or Not. Am, J. Clin.Nutr. 81 (suppl) : 268S-76S.

Handarini. R, E. Saleh, dan B. Togatorop. 2008. Produksi Burung Puyuh yang Diberi Ransum dengan Penambahan Tepung Umbut Sawit Fermentasi. Jurnal Agribisnis Peternakan. 4:107110.

Harborne, J. B. 1987. Metode Fitokimia Penuntun Cara Modern Menganalisis Tumbuhan. Terbitan Kedua. Institut Teknologi Bandung. Bandung. p123129. 
Hidayat, R. S dan R. M. Napitupulu. 2015. Kitab Tumbuhan Obat. Swadaya Grup. Jakarta.

Kurniasih. D, Mohammad Basuki. R, Catur Rahmat. H, dan Afif Zuhri. A. 2017. Pembuatan Pakan Ternak dari Limbah Cangkang Kerang di Desa Bulak Kenjeran Surabaya. Seminar master PPNS. Jurusan Teknik Pemesinan Kapal. Jurusan Teknik Kelistrikan Kapal. Politeknik Perkapalan Negeri Surabaya. Surabaya.

Lee S, A. L Simons, P. A Murphy and S. Hendrich. 2005. Soya Saponins Lowered Plasma Cholesterol and Increased Fecal Bile Acids in Female Golden Syrian Hamters. Experimental Biology and Medicine. 230 : 472-8.

Leeson, L and John. D. S. 2005. Commercial Poultry Nutrition. $3^{\text {th }}$ Ed. Department of Animal and Poultry Science. University of Guelph. Canada.

Messina, MJ. 1999. Legumes and Soybeans : Overview of Their Nutritional Profiles and Health Effects. American Journal of Clinical Nutrition. 70:439S-50

Mushawwir A. dan D. Latipuddin. 2013. Biologi Sintesis Telur, perspektif Fisologi, Biokimia dan Molekuler Produksi Telur. Penerbit Graha Ilmu, Yogyakarta.

Mushawwir, A. 2015. Biokimi Nutrisi. Widya Padjadjaran, Bandung.

National Research Council. 1994. Nutrient Requirements of Poultry. 9th Revised Edition. National Academy of Sciences. Washington, DC.

Nixon, TM. 2008. Sukses Beternak Puyuh. Penerbit Agromedia Nusantara. p105107.

Nugraha, Elisha. 2017. Mineral B-12. PT. Eka Farma. Semarang. www.ekafarma.com (Diakses 20 Januari 2019).

Nuraini, Sabrina dan S. A. Latif. 2012. Penampilan dan Kualitas Telur Puyuh yang Diberi Pakan Mengandung Produk Fermentasi dengan Neurispora crassa. Jurnal Peternakan Indonesia. $14: 23-28$
Robinson, T. 1995. Kandungan Organik Tumbuhan Tinggi. Edisi VI. Hal. 191216. Diterjemahkan oleh Kosasih Padmawinata. Institut Teknologi Bandung. Bandung.

Rosi, Nadia. 2018. Pengaruh Ekstrak Etanol Daun Kepel (Stelechocarpus kepel) terhadap Kadar Kolesterol Total dan Trigliserida Mencit yang Diinduksi Aloksan. Skripsi. Farmasi Klinik dan Komunitas. Fakultas Farmasi. Universitas Jember. Jember.

Saraswati, T. R., W. Manalu., D. R. Ekastuti., N. Kusumorini. 2013. Increase Egg Production of Japanese Quail (Coturnix-coturnix japonica) by Imroving Liver Function Through Turmeric Powder Supplementation. International Journal of Poultry Science. 12:601-614.

Sunarni T, Suwidjiyo P dan Ratna A. 2007. Flavonoid Antioksidan Penangkap Radikal Bebas dari Daun Kepel (Stelechocarpus kepel I (BI) Hook f \& Th). Majalah Farmasi Indonesia. 18:111-116.

Wang J. B, H.P Zhao, YL Zhao, C. Jin, D. J Liu, W. J Kong. 2011. Hepato Toxicity or Hepatoprotection Pattern Recognition for The Paradoxital Effect of The Chinese Herb Rheum palmatum in Treating Rat Liver Injury. PloS One. 6:24498

Yokozawa, T., T. Nakagawa, and K. Kitani. 2002. Antioxidative Activity of Freen Tea Polyphenol in Cholesterol Fed Rats. Journal of Agricultural and Food Chemistry. 50:3549-35. 